\title{
European Higher Education Area Establishment and Equal Opportunities: A Sociological Analysis of the Bologna Process Official Decisions
}

\author{
Gerasimos Koustourakis \\ Department of Educational Science and Early Childhood Education, \\ University of Patras, Greece. \\ E-mail: koustourakis@upatras.gr \\ Nikolaos Sklavenitis \\ Ministry of Education and Religious Affairs, Athens, Greece. \\ E-mail: nsklav@outlook.com
}

\section{Doi:10.5901/jesr.2013.v3n3p261}

\begin{abstract}
This work tries to analyze the official discourse on the development of a European Higher Education Area and focuses on the issue of equal opportunities of access to and completion of study in higher education. For this aim official documents of the first decade of the 21 st century referring to the Bologna process (communiqués and declarations of the Bologna process ministers responsible for higher education) were studied using the qualitative content analysis. The results of this work showed that the question of equal opportunities was included in the priority of the social dimension and occupied the Bologna process mainly from the year 2005 and on although mentions for equal opportunities to higher education studies exist in all Bologna process communiqués. The priority of social dimension was the outcome of the adaptation of human capital theory and mainly involved notions such as mobility, lifelong learning, students' socio-economic background, gender and underrepresentation.
\end{abstract}

Keywords: European Higher Education Area, equal opportunities, Bologna process, social dimension.

\section{Introduction}

The development of the European Higher Education Area (EHEA), widely known as the Bologna process (BP), has been characterized as the most important endeavour for the convergence of European countries policies for higher education (HE) (Adelman, 2009; Kwiek, 2004). This effort has as a starting point the Bologna Declaration of twenty-nine European ministers responsible for HE in 1999 aiming at the decision-making for the reform of European systems of HE so that to become more competitive internationally (Bologna Declaration, 1999). The BP today comprises 47 countries and even if all European Union (EU) countries participate in, it exceeds the limits of the EU. It has, however, been influenced by the EU and its education policy. Actually one could claim that the BP cannot be understood without connecting it with the EU higher education policy (Pépin, 2006).

The BP priorities and the development of the EHEA led to the creation of an exceptionally big number of scientific work referring to the following: a) the analysis of European educational priorities for the reform of the European higher education systems aiming at the development of the EHEA (Keeling, 2006; Kehm \& Teichler, 2006); b) the implementation of decisions for the EHEA in connection to the difficulties created because of the national particularities of the European education systems (EACEA/Eurydice, 2010, 2011; Furlong, 2005; Kwiek, 2004; Wächter, 2004); c) the assessment of consequences from the implementation of decisions for the EHEA in the BP countries (Kladis, 2005; Reinalda \& Kulesza, 2005); and d) the research, the approach and the analysis of the theoretical and ideological dimensions of the EHEA policy. Specifically, the liberal character of the European education policy and the effort of connecting $\mathrm{HE}$ to the labour market - an effort aiming at the creation of a European society and economy of knowledge (Naidoo, 2003; Ravinet, 2008). Additionally, the marketization in HE is demonstrated, as the modern reforms influencing the operation of universities and their programs of study are presented as an element of their modernization according to the demands of the market (Mayo, 2009; Middleton, 2000; Naidoo, 2003). Researchers have also dealt with the internationalization of universities and the changes to the institutions for corresponding to the demands of a particular type of educational service to students confronting them as customers - consumers (Harris, 2005; Stier \& Börjesson, 2010). A tendency of predominance of an audit culture in HE is presented as connected to the mechanisms of evaluation and quality assurance (Beck, 1999; Beck \& Young, 2005; Bonal, 2003; Murphy, 2009; Stamelos \& Kavasakalis, 2011; 
Vidovich, 2004).

The research of views and decisions of the official bodies of the BP on the issue of the equal opportunities and their attempt to deal with inequalities during the effort of developing the EHEA seems to be of sociological interest. And this is so because their decisions seem to influence the modern policy making for HE globally (Adelman, 2009). The BP communiqués and declarations certainly have influenced the EU policy making and vice versa (Pépin, 2007). The issue of equal opportunities can be found in the discussions of BP ministers responsible for HE on the priority of social dimension as their decisions seek to promote a participative equality of citizens in HE (Kladis, 2003, 2005; Rauhvargers et.al., 2009).

The objective of this work is the approach and critical analysis of the official meetings decisions of the BP ministers responsible for higher education during the establishment of the EHEA at the first decade of the 21st century as far as the issues of equal opportunities and the removal of inequalities are concerned. This subject seems interesting because of the global economic crisis, which causes intense agitations in modern Europe.

The study begins with the theoretical remarks. The research question and the methodology follow and then the results of the research are presented. Finally, this work is completed with the part of discussion and the concluding remarks.

\section{Theoretical remarks}

After the end of War World II, even though it was crucially questioned in the 1970s due to the consequences of the oil crisis, human capital theory gave the ideological frame for educational reforms in western and in developing countries (Koustourakis, 2011). International organizations such as UNESCO and OECD contributed substantially to the spread of the human capital theory ideas through their actions proposing to their member states: to increase investments to education in order to confront illiteracy; to expand compulsory education; and to create skilled labour force (Frangoudaki, 1985; OECD, 1998; UNESCO, 2004). This policy was expected to contribute to the needs of the labour market and to the confrontation of social inequalities bringing economical and social prosperity (Dreeben, 1968; Frangoudaki, 1985; Koustourakis, 2011; Parsons, 1959).

In the Community, the cooperation in education started in 1971 when the ministers of education met for the first time (Pépin, 2007). In 1972 in Paris the Community heads of state of that time adopted the principle of equal opportunity according to the human capital theory argumentation. In 1973 the so-called Jane report (it came from professor Henri Jane) gave to the Commission the guidelines of cooperation in HE (Corbet, 2012). In 1974 the Community ministers of education declared the principles which influenced the way the education was approached until the Maastricht treaty. In this declaration it was not aspired the harmonization of European education systems and there was a reference to the education of migrant workers' children and to equal opportunities to free access to all forms of education (Corbet, 2012; Pépin, 2006). The first Community action programme was adopted in 1976 at Council level on the basis of a resolution. It was not a strong legal act - as they are not the BP texts today. It took into account the diversity of national education systems and did not try to harmonize them (Pépin, 2006, 2007). The resolution of 1976 was the foundation of future cooperation in education and comprised the concept of equal opportunities for promoting European unity (Pépin, 2006).

In the 1990s was prepared the rhetoric and the political theses as regards the targets the European education should aim at. During the 1990s with steps such as the Amsterdam treaty (1997), it was promoted the wider access to education (Pépin, 2007). This decade ended with the Sorbonne and Bologna declarations. In 2000, at the EU level, emerged the Lisbon Strategy. In the new era of globalization that we describe, the influence of the economic factor is of primary importance for the formulation of education issues (Giddens, 2008). After the treaty of Maastricht in 1992 the policies were aiming at the economic improvement of Europe and education was confronted as a productive investment contributing to the creation of a society and economy of knowledge (Commission 1995). These views draw their argumentation upon the human capital theory, which constitutes the dominant epistemological paradigm for the modern education policy-making in the era of globalization (Beck, 1999; Bonal, 2003; Jones, 2005; Koustourakis, 2011; Mayo, 2009). The UNESCO, the World Bank and the OECD contributed to the dynamic reappearance of the views of the human capital theory in this period (Koustourakis, 2011; Nova-Kaltsouni, 2010; OECD, 1998; Scheerens, 2005; UNESCO, 2004).

In 1998 at the EU level, at the same period with the implementation of policies for the monetary union raised the idea of the harmonization of European systems of HE. The idea was proposed by the ministers responsible for HE of Germany, France, Italy and the United Kingdom. These ministers met in Sorbonne (1998) and declared the principles on which the harmonization of European systems of HE (Sorbonne Joint Declaration, 1998) would be based so that the 
improvement of competitiveness of the EU within the framework of global economy is achieved (Mayo, 2009; Naidoo, 2003; Nova-Kaltsouni, 2010).

The spreading of Information and Communication Technology (ICT) contributed to this as well as its diffusion in various sectors of the labour market. The modern era is seen as the era of the new economy and society of knowledge which is based on ICT (Castells, 2000). This fact led to the adaptation of the human capital theory as the emphasis is now given in the qualitative dimension of knowledge related to the significance of training. Thus the acquisition of skills is sought by the European citizens to make them able to manage the knowledge and the information covering the needs existing in the various sectors of employment. Besides, the frequent changes in the organization of production disdain the special knowledge and encourage the acquisition of a general body of knowledge and skills that should be renewed and adapted to the needs of the labour market (Nova-Kaltsouni, 2010).

The current educational policies, which are promoted in the USA and in Europe, are justified by the argument of a need for a close connection between education and economy. Thus the operation of universities is promoted based on the competitive terms of the market and the knowledge is seen as a commodity sold to those students/customers interested in acquiring it (Apple, 2001, 2007). Yet a gradual reduction of the HE institutions public funding is observed as well as their funding dependence on the private sector, a fact that gradually leads to the loss of their administrative and scientific autonomy (Apple, 2001; Noble, 2001). These developments led to the implementation of neo-liberal educational reforms justified by the use of an economical terminology (Apple, 2000; Daun, 2002; Popkewitz, 2000). It is very characteristic the fact that in the official discourse of the modern educational policy particular terms are pointed out such as economic rationality, privatization, choice, consumption and accountability (Apple, 2001; Ball, 2003; Harvey, 2003). These particular meanings are also developed in the content of the BP official documents (Leuven Communiqué, 2009; Mayo, 2009). There seems also to be a promotion and predominance of an audit culture in the field of $\mathrm{HE}$, in which the operation of universities is assessed on the basis of the principles of efficiency, their connection to the labour market and their continuous evaluation as far as the quality of educational services provided is concerned (Apple, 2007; Murphy, 2009). This theoretical point of view is depicted in the official documents of the institutional agents which are involved in the attempt of promoting the Bologna process such as European Universities Association (ENQA, 2009). In this case the view promoted is that the quality assurance is the most successful part of the BP with the development, advancement and improvement of doctoral education and research training in Europe, which constitutes "a major priority for European universities" (EUA, n.d.).

The educational policies that have been worked out having as their ideological background the views of the human capital theory led to an attempt of widening the access of all citizens to education and particularly to its upper level (Kelpanidis, 2002). The issues of dealing with inequalities and the facilitation of access of all citizens to HE were first brought up by the UNESCO and the OECD during the 1990's (Goastellec, 2011). The views of these international organisations together with stakeholder organisations (such as the European Student Organisation, the Council of Europe and the European University Organisation) a decade later influenced the framework of the development of EHEA and the objective of facilitating the access of European citizens in HE. The social dimension today is considered as a basement principle of the EHEA foundations which is restated and readjusted through the years (Zgaga, 2012).

\section{Research Questions - Methodology}

The research question of this work is: How the issue of equal opportunities and the confrontation of inequalities in HE is approached by the Bologna process ministers responsible for HE who promoted the development of the EHEA during the first decade of the 21st century?

In this work, we will try to answer our question through a critical reading and the use of the qualitative content analysis (Dey,1993) of the sources, referring to the theoretical and practical choices for the shaping and assessment of the policy followed for the development of the EHEA (Dale, 1989; Koustourakis, 2007). This concerns: a) the communiqués and the declarations of the BP ministers responsible for HE (Bologna Declaration, 1999; Prague Communiqué, 2001; Berlin Communiqué, 2003; Bergen Communiqué, 2005; London Communiqué, 2007; Leuven/Louvain-La-Neuve Communiqué, 2009; Budapest-Vienna Declaration, 2010); and b) the conclusions and resolutions of the European Council in higher education within the EU area (Council, 2007, 2009, 2010; European Commission, 2006, 2010). Moreover, one official Bologna Follow Up Group document (Rauhvargers et. al., 2009), four reports from the European Students' Union (ESIB, 2005, 2007; ESU, 2009, 2010) and two EU official publications dealing with the BP (EACEA/Eurydice, 2010, 2011) are used as sources.

Afterwards follows a qualitative analysis of the BP official discourse in relation to the issues of equal opportunities 
and the effort to deal with inequalities of access to and the completion of study in HE (the priority of social dimension) within the framework of the development of the EHEA.

\section{Presentation and analysis of research findings}

The Bologna Declaration was the starting point for trying to develop the EHEA as it set the priorities for this endeavour. In Bologna (1999) was held a meeting of ministers responsible for the HE policy of the European countries. In the outcome of their meeting the issue of educational inequalities was not approached (Kladis, 2005). The opinions expressed in the Bologna Declaration were within the framework of technological functionalism and human capital theories. Indeed, the idea of the creation of competitive European HE systems that will contribute to the economic growth and prosperity in globalization was formulated with clarity (Bologna Declaration, 1999). The issue of taking measures against education inequalities was discussed for the first time by the BP ministers in the meeting of Prague (2001) after intervention by the representatives of European Students Union whose proposals were adopted and incorporated in the Prague Communiqué (Kladis, 2003; Rauhvargers et. al., 2009). Towards the statements for the social dimension and the equal opportunities, an important contribution was also made by the professors of European universities, who participated in the meeting of Prague (Kladis, 2003).

Table 1 shows the decisions of the Bologna process HE ministers for the promotion of equality of educational opportunities (i.e. decisions for the promotion of the priority of the social dimension) as well as their proposed interventions for their implementation.

Table 1. Decisions made on the promotion of equality of educational opportunities and proposed interventions for their implementation (2001-2010).

\begin{tabular}{|c|c|c|c|}
\hline Communiqué & Year & Areas and sectors of interest & Suggested interventions \\
\hline Prague & 2001 & Mobility, Lifelong learning. & - Informative seminars. \\
\hline Berlin & 2003 & $\begin{array}{l}\text { Lifelong } \\
\text { economic } \\
\text { gender. }\end{array}$ & $\begin{array}{l}\text { - Mobility and international academic cooperation. } \\
\text { - Improvement of infrastructures and operation of } \\
\text { institutions. } \\
\text { - Statistical imprinting. }\end{array}$ \\
\hline Bergen & 2005 & $\begin{array}{l}\text { Social dimension and } \\
\text { unprivileged social groups. } \\
\text { National policies for higher } \\
\text { education. }\end{array}$ & $\begin{array}{l}\text { - Guidance and counselling services. } \\
\text { - Economic support of students. } \\
\text { - Improvement of infrastructures and operation of } \\
\text { institutions. }\end{array}$ \\
\hline London & 2007 & $\begin{array}{l}\text { Social dimension and socio- } \\
\text { economic background of } \\
\text { students, lifelong learning. }\end{array}$ & $\begin{array}{l}\text { - Reforms in higher education. } \\
\text { - Flexible learning pathways and lifelong learning. } \\
\text { - Assessment. }\end{array}$ \\
\hline $\begin{array}{l}\text { Leuven/ Louvain- } \\
\text { La-Neuve }\end{array}$ & 2009 & $\begin{array}{lr}\text { Lifelong learning, } & \text { Social } \\
\text { dimension } & \text { and } \\
\text { underrepresented } & \text { social } \\
\text { groups. } & \end{array}$ & $\begin{array}{l}\text { - Reforms in lower levels of education. } \\
\text { - Increase in the access to higher education till } 2020 . \\
\text { - Economic support. } \\
\text { - Improvement in the operation of institutions. } \\
\text { - Assessment. }\end{array}$ \\
\hline Budapest-Vienna & 2010 & $\begin{array}{ll}\text { Underrepresented } & \text { social } \\
\text { groups, socialization. } & \end{array}$ & $\begin{array}{l}\text { - Inclusion of European citizens in higher education. } \\
\text { - Mobility and international collaborations. }\end{array}$ \\
\hline
\end{tabular}

The data of Table 1 show that from the meeting of Prague and on there is an evolution in the discussions concerning what sectors and areas will be taken into account so that to promote the issue of equity in $\mathrm{HE}$ (i.e. the social dimension).

In the Prague Communiqué we can see the intervention of the European Students Union that participated in the meeting:

"Ministers (...) reaffirmed the need, recalled by students, to take account of the social dimension in the Bologna process" (Prague Communiqué, 2001, p. 3).

Thus, the promotion of academic community mobility was decided. For supporting this decision the ministers decided on informative seminars as well as on the examination of ways for "the removal of all obstacles to the free movement of students, teachers, researchers and administrative staff" (Prague Communiqué, 2001, p. 2). A remark was made on the need of activating lifelong learning provided by HE institutions as it was stressed that "lifelong learning strategies are 
necessary to face the challenges of competitiveness and the use of new technologies and to improve social cohesion, equal opportunities and the quality of life" (Prague Communiqué, 2001, p. 2).

The question of incorporating lifelong learning in $\mathrm{HE}$ was given a greater emphasis in the meeting of the BP ministers responsible for HE in Berlin (2003):

"[Ministers] stress the need to improve opportunities for all citizens, in accordance with their aspirations and abilities, to follow the lifelong learning paths into and within higher education" (Berlin Communiqué, 2003, p. 6).

The discussions in Berlin on the confrontation of inequalities were more essential compared to those of the meeting in Prague (Kladis, 2005). From the relevant communiqué it is clear that HE was seen as a public good that will have to be used for "strengthening social cohesion and reducing social and gender inequalities both at national and at European level" (Berlin Communiqué, 2003, p. 1). Another position expressed was that equity in the access to HE could be achieved provided that the "appropriate studying and living conditions for the students" were created (Berlin Communiqué, 2003, p. 5). For this reason they encouraged mobility, as they did in Prague, and the "international academic cooperation and exchanges, [where] academic values should prevail" (Berlin Communiqué, 2003, p.1). Still there seems to prevail a parsonian perception that the assurance of equal opportunities depends on the skills of someone willing to study (Blackledge \& Hunt, 2002). Equal opportunities can be achieved in two ways: by removing the obstacles concerning the material conditions of study (living conditions, material and technical infrastructure); and by improving interventions in the operation of $\mathrm{HE}$ institutions (programs of study, process of teaching and learning). The meeting of the ministers in Berlin, under the pressure of the European Students' Union for the promotion of the social dimension (ESIB, 2005, pp. 3-4), decided on the realization of a research work from which results about the effectiveness of the institutions of higher education could be derived, as well as about the "social and economic situation of the students" studying in them (Berlin Communiqué, 2003, p. 5). This decision led to specific studies monitoring the social and economic situation of students financed by the EU (see: Camilleri \& Mühleck, 2010; Eurostat, 2009; Orr et.al., 2009; Orr et.al., 2011). In addition, the EU funded the publication of research works made by the European Students Union presenting the Bologna process through students' eyes (ESIB, 2005, 2007; ESU, 2009, 2010).

The meeting in Bergen in 2005 was a turning-point in the effort of dealing institutionally with inequalities that concern the access to and the completion of study in HE. It was in this meeting that the priority of "social dimension" was set with clarity as one of the most important priorities of the BP, one that should be promoted through the national policymaking for $\mathrm{HE}$ :

\begin{abstract}
"The social dimension of the Bologna Process is a constituent part of the EHEA and a necessary condition for the attractiveness and competitiveness of the EHEA (...) the social dimension includes measures taken by governments to help students, especially from socially disadvantaged groups, in financial and economic aspects and to provide them with guidance and counselling services with a view to widening access" (Bergen Communiqué, 2005, p. 4).
\end{abstract}

The action lines of Bergen completed those of Berlin for the improvement of infrastructures and conditions of operation of HE institutions, as well as those for the process of providing the benefit of study to students. For the first time a dialog took place for the need of developing national strategies that will help the access of citizens from unprivileged societal groups to HE. More specifically, the proposals for specific interventions for decreasing social inequalities were focused on two sectors: on professional orientation so that the students of secondary education be informed about the existing educational opportunities and be guided to choose the educational path that suits them, and on the economic support of students coming from unprivileged socio-economic groups.

The need of taking full advantage of HE for social cohesion and for the reduction of inequalities appeared with a great emphasis in the meeting of the BP ministers in London in 2007. In that meeting it was decided that the European states will have to make reforms that will contribute to the removal of obstacles related to the socio-economic factors. And this because "the student body entering, participating in and completing $\mathrm{HE}$ at all levels should reflect the diversity of our populations". Also the educational reforms should create chances for "more flexible learning pathways into and within HE, and to widen participation at all levels on the basis of equal opportunity" (London Communiqué 2007, p. 5). Therefore, the London meeting set and clarified the representation of all societal groups in HE and the flexibility in studies. Members from all societal groups comprising the European societies should be able to follow graduate and postgraduate education and training as they wish. The flexibility is connected not only to the incorporation of lifelong learning in $\mathrm{HE}$ but also to the evaluation of the European systems of $\mathrm{HE}$ so that it will be ensured that the decisions on the EHEA and more specifically those concerning mobility will be applied (London Communiqué, 2007).

From the study and analysis of the official discourse of the BP ministers on the EHEA it comes out that the need of 
the confrontation of inequalities in HE because of socio-economic reasons is set with emphasis at the end of the first decade of the $21^{\text {st }}$ century. And this because during the first years of the BP implementation, it was considered that the competitiveness of European HE would come via the reformation of study programs, the internationalization of universities and the comparability of degrees. During the first years of the EHEA development there was no concern about widening access to HE even though there was a reference for equal opportunities, because of the European Students Union participation (ESU, 2009). The change in the agenda partly resulted from the consequences of the rising economic crisis. It is characteristic that the questions of social dimension and the benefit of equal opportunities in the access to and the completion of HE studies were once more placed in the centre of discussions of Bologna process HE ministers in Leuven (2009). In 2009 the quest of widening the attendance of members of underrepresented groups at HE was set and clarified. An innovation of the Leuven meeting appears to be the need for reforms in the lower levels of education so that it would be possible to have a wider access of citizens to the universities (Leuven Communiqué, 2009). The need of taking full advantage of "lifelong learning as an integral part of our education systems" (Leuven Communiqué, 2009, p. 3) was stressed as important for widening attendance at HE. For the promotion of equal opportunities the European states were asked to provide economic support to students that come from vulnerable socioeconomic groups. Furthermore, the need of changes in HE institutions operation was stressed as "this involves improving the learning environment, removing all barriers to study" (Leuven Communiqué, 2009, p. 2) that complicate the educational effort of some students. In Leuven the time limit of 2020 was set. By that time the European states should apply policies for underrepresented groups in HE. Once more there was made a point on the issue of evaluation of European $\mathrm{HE}$ in order to assess the degree of implementation of the decisions on the BP promotion (Leuven Communiqué, 2009).

In the meeting of Budapest/Vienna in March 2010 the European ministers supported that the first phase of the BP was completed and they reaffirmed the decisions of the Leuven Communiqué. They also repeated that "paying particular attention to underrepresented groups" (Budapest-Vienna Declaration, 2010, p. 2) was important in order these groups to acquire access to $\mathrm{HE}$. And this because it appears that it is promoted the socialization of students through the HE institutions: (i) to a profession that will cover the needs of the labour market (and therefore the acquisition of practical skills is required by them) (Rauhvargers et. al., 2009); and (ii) to certain common European values since it is stressed "the role the higher education institutions play in fostering peaceful democratic societies and strengthening social cohesion" (Budapest-Vienna Declaration, 2010, p. 2). The last target takes place through the implementation of mobility of staff and students and the collaboration between the European $\mathrm{HE}$ institutions. And it is still strengthened by the effort of including all European citizens in $\mathrm{HE}$ independently from their racial and ethnic origin:

"We strive for the societal goal that the student body entering, participating in and completing higher education should reflect the diversity of our populations" (Rauhvargers et.al., 2009, $\sigma .124$ ).

The discourse of institutional bodies of the European Union concerning the confrontation of inequalities has the same character (as it moves in the same direction) with the discourse of the ministers responsible for HE of the countries participating in the BP. More specifically, in the EU official documents, the objective of the assurance of equality of educational opportunities for all Europeans and especially for the members of underrepresented social groups is connected to (Council, 2007, 2009, 2010): (i) lifelong learning; (ii) the modernization of universities in order to contribute to the improvement of economical competitiveness of the EU; and (iii) the acquisition of skills by the students so that they increase the prospects of finding an occupation. This fact is considered to shape active European citizens that will promote the social cohesion with their actions.

Despite the decisions taken by the European ministers participating in the $\mathrm{BP}$, the national policies of the European countries concerning the lifting of inequalities of access to and completion of study in HE have not been effective yet. Some positive interventions have been in place through the years. However, individuals coming from unprivileged societal groups do continue finding themselves in an unfavorable situation in regard to the studies in HE (EACEA/Eurydice, 2010, 2011; ESIB, 2005, 2007; ESU, 2009, 2010).

\section{Discussion and Concluding Remarks}

The development of the EHEA is closely connected to the Lisbon Strategy according to which the EU was planned to be a strong and competitive entity based on knowledge by the year 2010 (Council, 2007; European Commission, 2006; Keeling, 2006; Wächter, 2004). In this effort great importance was given to HE to provide the necessary scientific education and training corresponding to the existing needs of the labour market. That is why it is considered that the 
modernization of higher institutions will contribute to the achievement of this target:

"this crucial sector of the economy and of society needs in-depth restructuring and modernisation if Europe is not to lose out in the global competition in education, research and innovation" (European Commission, 2006, p. 11).

However, as Kladis (2005) points out the issue of equal opportunities in the BP was the object of political and ideological juxtapositions. On one side the views were focused on competitiveness through the quality assurance of the provided education and on the other side on the social dimension and the approaching of HE as a public good. This does not of course imply that when someone focuses on the social dimension does not pay attention to quality issues (Apple, 2007; Ball, 2003; Bonal, 2003; Harvey, 2003; Kwiek, 2004). The effort of incorporating elements that satisfy the requirements of certain societal groups in the current educational policy (like mobility of students) is connected to the need of acceptance of this policy and reduction of social resistances during the process of its implementation (Apple, 2008). Indeed the preoccupation of the Bologna process ministers with equal opportunities to HE takes place in 2001 thanks to the pressure made by the side of the European Students' Union (ESIB, 2009). However, although the students fought against the idea of introducing tuition fees in continental European universities the objective was not achieved because of: i) the heterogeneity (although BP principles cannot be confronted as "once-and-for-all" notions) in the policy for the higher education among the countries (Brohonnek, 2010); and ii) the predominance of a neo-liberal logic leading to the gradual withdrawal of the state from funding higher education and creating the need to the institutions to fill in the funding gap by operating as commercial enterprises (Apple, 2000, 2007; Ball, 2003; Bonal, 2003). Thus the citizens are approached as consumers of educational services and the solutions in the study issues lie in their individual initiative and inventiveness (Apple, 2001). In the frame of this policy, for the support of financially vulnerable students and for the facilitation of students mobility a system of grants and loans was developed in the majority of participating countries in the Bologna process, which was evaluated positively by the European Students' Union (ESIB, 2005).

The official discourse of the BP ministers and of the pertinent bodies which promotes the need of modernization of European $\mathrm{HE}$ aiming at a better management of the human capital is also connected to the policies of increasing the number of population that will have access to $\mathrm{HE}$ and to the new knowledge (Kelpanidis, 2002). In the communiqués of the ministers' every two-year scheduled meetings on the development of the EHEA, the issue of representation in higher education of all societal levels and groups that compose the populations of the various European states is set with clarity from 2005 and on.

The number of general mentions existing in the BP official discourse for the provision of equal opportunities of access to and the completion of study in HE reveals that the decisions on the development of the EHEA are results of compromises. The view that prevailed in the beginning of the first decade of the 21st century supports that the improvement of competitiveness of European institutions of higher education can result from the redevelopment of programs of study, the comparability of degrees, the collaborations between universities and the mobility of teachers and students. This view specializes the Bologna Declaration approach and leads to neoliberal educational political choices, which are based on arguments reflecting an audit culture, the accountability and the marketization of programs of study (Apple, 2007, 2008; Beck \& Young, 2005; Bonal, 2003; Murphy, 2009). In this case the confrontation of inequalities is a question of lower importance. Moreover, from the study of the BP communiqués it is clear that in 2001 there is no prompting to the European states for specific actions. Furthermore, the decisions made in 2001, 2003 and 2005 in regard to the realization of seminars on the subject of lifting the obstacles to mobility, the creation of comparable data for students, the improvement of opportunities for lifelong learning and the creation of comparable research data constituted the action lines for the national policies on HE.

An important change in the approach of the issue of equal opportunities and of overcoming social inequalities emerges in 2005 and in 2007, where the neoliberal view of education is combined to the human capital theory. Indeed, the decisions taken by European ministers are harmonized with the corresponding proposals of international organizations, such as the UNESCO (Goastellec, 2011; UNESCO, 2004). More specifically, there are references on the configuration of national policies that will encourage in the future the access of citizens from unprivileged societal groups to $\mathrm{HE}$. And this happens so that they acquire the essential knowledge and qualifications and contribute, on their side, to the effort for economic growth. In London (2007) it was decided that the efforts for widening the attendance at HE should be continued aiming at the improvement of provided supporting services to students, at their economic and advisory support, and at the creation of flexible learning pathways towards and within HE (London Communiqué, 2007). In 2009 it was decided that the attendance at HE should be widened with students from underrepresented groups. In 2009 it was set the time limit of 2020 so that the European states adjust their policies for HE and ensure the access of children from unprivileged and underrepresented groups. For this aim, each country participating in the BP was called to set specific 
and measurable targets that would lead to reforms in the lower levels of education so that the education process of students belonging to the specific groups is supported (Leuven Communiqué, 2009).

Consequently, important decisions were taken by the European ministers responsible for HE in London and in Leuven, which constitute the action lines for the implementation of reforms that are considered necessary to promote the target of equal opportunities for the access of European citizens to HE. Based on the soft-law character of the BP communiqués and declarations, the prevailing view is that each state according to its national particularities will create by the year 2020 its own plan of action for overcoming inequalities. That is probably why it is mentioned by the institutional bodies of the BP that there is still much to be covered in order to have specific acceptable results (see mention in Rauhvargers et. al., 2009). Moreover, it appears that there is a discrepancy between the decisions taken at a central European level and the policies applied at a national level. This happens because of the existing different perceptions among the Bologna process countries concerning the way and the time of realization of the priorities of the meetings (ESU, 2009, 2010; Eurostat, 2009).

Despite the fact that from 2005 and on the priority of the social dimension is presented as one of the basic priorities for the shaping of the future field of higher education in Europe, this dimension is faced as less important by a big number of countries participating in the BP (EACEA/Eurydice, 2011). The promotion of the priority of the social dimension is connected to the perception of human capital theory saying that the opening of universities to citizens will provide them with the necessary education and training to be able to cover the needs of the labour market in the society and economy of knowledge (Kelpanidis, 2002; UNESCO, 2004). However, the modern national HE policies appear to be influenced more by the opinions of a neoliberal logic approaching the education through the use of the economic terms of the market. In this case, it is considered that the quality assurance of educational institutions is the key that will ensure their competitiveness globally and not the widening of attendance of citizens at HE (Apple, 2001, 2007). In this frame it is characteristic the negative reaction of students pointing out that "the European Student Union (ESU) sees that it is a shame that no real action has been taken over the past ten years, to develop the social dimension of the European Higher Education Area" (ESU, 2010, p. 91). And this is so because:

\footnotetext{
"In the face of the current economic situation, an increasing number of Governments are neglecting their responsibility to higher education, by making funding-cuts, with, inevitably, students suffering the consequences. The results of these cuts are increasing tuition fees and higher debt, combined with bigger loan payments, decreased opportunities to obtain loans and grants, and reductions in student support" (ESU, 2010, p. 113).
}

Consequently, according to the European students the European higher education policies during the economic crisis seem to cancel the effort for the promotion of social dimension.

As a second phase is still going on during the second decade of the 21st century, the approach and evaluation of ways of implementing at European and at national level policies concerning equal opportunities in education, through the opening of the universities to all European citizens, seems to have research interest. The principles of the BP are concepts in progress and they have different interpretations according to the various national frameworks (Zgaga, 2012). The existence of different national values and views may affect negatively the implementation of the priority of social dimension. It would therefore be of interest to examine the approach, revelation and interpretation of resistances and difficulties that exist at a national level and prevent, delay or cancel any efforts of overcoming inequalities in higher education. Finally, it would be interesting to analyze the national interventions of different countries in promoting the Bologna process goals for the creation of the EHEA as well as of a global higher education area.

\section{References}

Adelman, C. (2009). The Bologna Process for U.S. eyes: Re-learning higher education in the age of convergence. Washington, DC: Institute for Higher Education Policy.

Apple, M.W. (2000). Between neoliberalism and neoconservatism: Education and conservatism in a global context. In N.C. Burbules, \& C. A. Torres (Eds.), Globalization and education: Critical perspectives (pp. 57-77). New York: Routledge.

Apple, M.W. (2001). Educating the "right" way: Markets, standards, God, and inequality. New York: Routledge.

Apple, M. (2007). Education, markets, and an audit culture. International Journal of Educational Policies, 1(1), 4-19.

Apple, M. (2008). Official knowledge. Athens: Epikentro.

Ball, S. (2003). The more things change: educational research, social class and "interlocking inequalities." London: Institute of Education. University of London.

Beck, J. (1999). Makeover or takeover? The strange death of educational autonomy in neo-liberal England. British Journal of Sociology of Education, 20(2), 223-238.

Beck, J., \& Young, M.F.D. (2005). The assault on the professions and the restructuring of academic and professional identities: a Bernsteinian 
analysis. British Journal of Sociology of Education, 26(2), 183-197.

Bergen Communiqué (2005). The European Higher Education Area - Achieving the Goals. [Online] Available: http://www.bolognabergen2005.no/Docs/00-Main_doc/050520_Bergen_Communique.pdf (November 10, 2011).

Berlin Communiqué (2003). Realising the European Higher Education Area. [Online] Available: http://www.bolognaberlin2003.de/pdf/Communique1.pdf (November 10, 2011).

Blackledge, D., \& Hunt, B. (2002). Sociology of education. Athens: Metaixmio.

Bologna Declaration (1999). Joint declaration of the European Ministers of education. [Online] Available: http://www.ond.vlaanderen.be /hogeronderwijs/bologna/documents/MDC/BOLOGNA_DECLARATION1.pdf (November 10, 2011).

Bonal, X. (2003). The Neoliberal Educational Agenda and the Legitimation Crisis: Old and New State Strategies. British Journal of Sociology of Education, 24(2), 159-175.

Brohonnek, A. (2010). Income and Expenditure. In A.F. Camilleri \& K. Mühleck (Eds.), Evolving Diversity. An Overview of equitable access to HE in Europe (pp. 63-84). [Online] Available: http://www.eurostudent.eu/download_files/documents /Evolving_Diversity.pdf (January 30, 2013).

Budapest - Vienna Declaration (2010). On the European higher education area. [Online] Available: http://www.ond.vlaanderen.be /hogeronderwijs/bologna/2010_conference/documents/Budapest-Vienna_Declaration.pdf (November 10, 2011).

Camilleri, A.F., \& Mühleck, K. (Eds.) (2010). Evolving Diversity. An Overview of equitable access to HE in Europe. [Online] Available: http://www.eurostudent.eu/download_files/documents/Evolving_Diversity.pdf (January 30, 2013).

Castells, M. (2000). The rise of the network society. Vol. 1 (2nd edn). Oxford: Blackwell Publishers.

Commission of the European Communities (1995). White paper on education and training - teaching and learning - towards the learning society. [Online] Available: http://europa.eu.int/comm/education/doc/official/keydoc/lb-en.pdf (November 15, 2011).

Corbet, A (2012). Principles, problems, politics...What does the historical record of EU Cooperation in higher education tell the EHEA generation? In A. Curaj et al (Eds.), European education at the crossroads: Between the Bologna process and national reforms (pp. 39-57). Netherlands: Springer.

Council of the European Union (2007). Council resolution on modernising universities for Europe's competitiveness in a global knowledge economy. [Online] Available: http://www.era.gv.at/attach/Council_Res.enNov07.pdf (November 10, 2011).

Council of the European Union (2009). Council conclusions of 12 May 2009 on a strategic framework for European cooperation in education and training. [Online] Available: http://eur-lex.europa.eu/LexUriServ/LexUriServ.do?uri =CELEX:52009 XG0528(01) :EN:NOT (November 10, 2011).

Council of the European Union (2010). Council conclusions of 11 May 2010 on the social dimension of education and training. [Online] Available: http://eur-lex.europa.eu/LexUriServ/LexUriServ.do?uri=OJ:C:2010:135:0002:0007:EN:PDF (November 28, 2011).

Dale, R. (1989). The state and education policy. Philadelphia, PA: Open University Press.

Daun, H. (2002). Conceptualization and results of educational restructuring. In H. Daun (Ed.) Educational restructuring in the context of globalization and national policy (pp. 71-112). London: RoutledgeFalmer.

Dey, I. (1993). Qualitative data analysis. London: Routledge.

Dreeben, R. (1968). On What Is Learned in School. Reading, MA: Addison-Wesley.

EACEA/Eurydice (2010). Focus on higher education in Europe 2010: The impact of the Bologna process. Brussels: EACEA P9 Eurydice. [Online] Available: http://eacea.ec.europa.eu/education/eurydice/documents/thematic_reports/122EN.pdf (November 10, 2011).

EACEA/Eurydice (2011). Modernisation of higher education in Europe: Funding and the social dimension 2011, Brussels: EACEA P9 Eurydice. [Online] Available: http://eacea.ec.europa.eu/education/eurydice/documents/thematic_reports/131EN.pdf (November 10, 2011).

ENQA (2009). Standards and Guidelines for Quality Assurance in the European Higher Education Area. Helsinki: European Association for Quality Assurance in Higher Education.

ESIB - The National Unions of Students in Europe (2005). Bologna with student eyes. [Online] Available: http://www.ehea.info IUploads/Documents/Bolognastudenteyes2005.pdf (January 30, 2013).

ESIB - The National Unions of Students in Europe (2007). Bologna with student eyes. [Online] Available: http://www.ehea.info/Uploads /Documents/Bolognastudenteyes2007.pdf (January 31, 2013).

ESU - The European Students' Union (2009). Bologna with student eyes. [Online] Available: http://www.ehea.info/Uploads /Documents/BolognaWithStudentEyes2009.pdf (January 31, 2013).

ESU - The European Students' Union (2010). Bologna at the finish line: An account of ten years of European higher education reform. [Online] Available: http://www.ehea.info/Uploads//rina/2010_Bologna\%20with\%20Student\%20Eyes.pdf (January 30, 2013).

EUA (n.d.). EUA Council for Doctoral Education. [Online] Available: http://www.eua.be/cde/Home.aspx (February 12, 2013).

European Commission (2006). Communication from the Commission to the Council and the European Parliament. Delivering on the modernisation agenda for universities: education, research and innovation [Online] Available: http:/lec.europa.eu/education /highereducation/doc1324 en.htm (November 10, 2011).

European Commission (2010). EUROPE 2020: A strategy for smart, sustainable and inclusive growth. [Online] Available: http://europa.eu/press_room/pdf/complet_en_barroso__007_-_europe_2020_-_en_version.pdf (November 15, 2011).

Eurostat (2009). The Bologna Process in Higher Education in Europe. Key indicators on the social dimension and mobility. [Online] Available: http://www.eurostudent.eu/download_files/documents/KS-78-09-653-EN.pdf (February 14, 2013).

Frangoudaki, A. (1985). Sociology of education. Athens: Papazisis.

Furlong, P. (2005). British higher education and the Bologna process: An interim assessment. Politics, 25(1), 53-61.

Giddens, A. (2008). Sociology. Cambridge: Polity.

Goastellec, G. (2011). Measuring inequalities in higher education: a politics of science. London Review of Education, 9(1), 71-82.

Harris, S. (2005). Professionals, partnerships and learning in changing times. International Studies in Sociology of Education, 15(1), 71-86.

Harvey, D. (2003). The new imperialism. Oxford: Oxford University Press.

Jones, K. (2005). Remaking education in Western Europe. European Educational Research Journal, 4(3), 228-242. 
Keeling, R. (2006). The Bologna process and the Lisbon research agenda: the European Commission's expanding role in higher education discourse. European Journal of Education, 41(2), 203-223.

Kehm, B. M., \& Teichler, U. (2006). Which direction for bachelor and master programmes? A stocktaking of the Bologna process. Tertiary Education and Management, 12(4), 269-282.

Kelpanidis, M. (2002). Sociology of Education. Athens: Hellinika Grammata.

Kladis, D. (2003). The social dimension of the Bologna process. Higher Education in Europe, 28(3), 353-354.

Kladis, D. (2005). The social dimension of the Bologna process and the route from Bologna to Prague and from Prague to Berlin. In N. Papadakis, \& D. Gravaris (Eds.), Education and educational policy: Between the state and the market (pp. 177-184). Athens: Savalas.

Koustourakis, G. (2007). The new educational policy for the reform of the curriculum and the change of school knowledge in the case of Greek compulsory education. International Studies in Sociology of Education, 17(1), 131-146.

Koustourakis, G. (2011). The use of the human capital theory argumentation to the institution of the Greek educational reform of 1997-1998 in general and technical-vocational education. Revista Educação Skepsis, 3(2), 2141-2176.

Kwiek, M. (2004). The emergent European educational policies under scrutiny: the Bologna process from a central European perspective. European Educational Research Journal, 3(4), 759-776.

Leuven/Louvain-La-Neuve Communiqué (2009). The Bologna process 2020 - the European higher education area in the new decade. [Online] Available: http://www.ond.vlaanderen.be/hogeronderwijs/bologna/conference/documents/Leuven_Louvain-la-Neuve_Communiqué_April 2009.pdf (November 18, 2011).

London Communiqué (2007). Towards the European higher education area: Responding to challenges in a globalised world. [Online] Available: http://www.coe.int/t/dg4/highereducation/ehea2010/London\%20Communique\%20-\%2018-05-2007.pdf (November 27, 2011).

Mayo, P. (2009). Competitiveness, diversification and the international higher education cash flow: the EU's higher education discourse amidst the challenges of globalisation. International Studies in Sociology of Education, 19(2), 87-103.

Middleton, C. (2000). Models of state and market in the 'modernisation' of higher education. British Journal of Sociology of Education, 21(4), 537554.

Murphy, M. (2009). Bureaucracy and its limits: Accountability and rationality in higher education. British Journal of Sociology of Education, 30(6), 683-695.

Naidoo, R. (2003). Repositioning Higher Education as a Global Commodity: Opportunities and Challenges for Future Sociology of Education Work. British Journal of Sociology of Education, 24(2), 249-259.

Noble, D.F. (2001). Digital diploma mills: The automation of higher education. New York: Monthly Review Press.

Nova-Kaltsouni, C. (2010). Sociology of education. Athens: Gutenberg.

OECD (1998). Human capital investment: An international comparison. [Online] Available: http://www.oecdbookshop.org/oecd/getit.asp?REF=9698021E.PDF\&TYPE=browse (February 15, 2012).

Orr, D., Schnitzer, K., \& Frackmann, E. (2008). Social and Economic Conditions of Student Life in Europe. Synopsis of indicators. Final report. Eurostudent III 2005-2008. Bielefeld: W. Bertelsmann Verlag.

Orr, D., Gwosc, C., \& Netz, N. (2011). Social and Economic Conditions of Student Life in Europe. Synopsis of indicators. Final report. Eurostudent IV 2008-2011. Bielefeld: W. Bertelsmann Verlag.

Parsons, T. (1959). The school class as a social system: Some of its functions in American society. Harvard Educational Review, 4(29), $297-318$.

Pépin, L. (2006). The history of European cooperation in education and training. Europe in the making: An example. Brussels: European Commission.

Pépin, L. (2007). The history of EU cooperation in the field of education and training: How lifelong learning became a strategic objective. European Journal of Education, 42(1), 121-132.

Popkewitz, T. (2000). Reform as the social administration of the child: Globalization of knowledge and power. In: N.C. Burbules, \& C. A. Torres (Eds.) Globalization and education: Critical perspectives (pp. 157-186). New York: Routledge.

Prague Communiqué (2001). Towards the European higher education area. [Online] Available: http://www.bologna-berlin2003.de/pdf /Prague_communiquTheta.pdf.(November 18, 2012).

Rauhvargers, A., Deane, C., \& Pauwels, W. (2009). Bologna, process stocktaking report 2009. [Online] Available: http://www.ond.vlaanderen.be /hogeronderwijs/bologna/actionlines/stocktaking.htm (February 15, 2012).

Ravinet, P. (2008). From voluntary participation to monitored coordination: why European countries feel increasingly bound by their commitment to the Bologna process. European Journal of Education, 43(3), 203-223.

Reinalda, B., \& Kulesza, E. (2005). The Bologna process: Harmonizing Europe's higher education, Leverkusen: Barbara Budrich Publishers.

Scheerens, J. (2005). The quality of education at the beginning of the $21^{\text {st }}$ century. Paper for the UNESCO education for all global monitoring report. Paris: UNESCO.

Sorbonne Joint Declaration (1998). Joint declaration on harmonisation of the architecture of the European higher education system. [Online] Available: http://www.bologna-berlin2003.de/pdf/Sorbonne_declaration.pdf (November 15, 2011).

Stamelos, G., \& Kavasakalis, A. (2011). The public debate on a quality assurance system for Greek universities. Quality in Higher Education, 17(3), 353-368.

Stier, J., \& Börjesson, M. (2010). The internationalised university as discourse: institutional self-presentations, rhetoric and benchmarking in a global market. International Studies in Sociology of Education, 20(4), 335-353.

UNESCO (2004). Higher education in a globalized society. Paris: UNESCO.

Vidovich, L. (2004). Global-national-local dynamics in policy processes: A case of 'quality' policy in higher education. British Journal of Sociology of Education, 25(3), 341-354.

Wächter, B. (2004). The Bologna process: Developments and prospects. European Journal of Education, 39(3), 265-273.

Zgaga, P. (2012). Reconsidering the EHEA principles: Is there a "Bologna philosophy"? In A. Curaj et al (Eds.), European education at the crossroads: Between the Bologna process and national reforms (pp. 39-57). Netherlands: Springer. 